\title{
Were Social Democratic Parties Really More Working Class in the Past?
}

\begin{abstract}
The goal of this chapter is to establish a baseline for the strength of the working-class character of social democracy in the decades following the Second World War in order to avoid any over- or underestimation. The chapter develops criteria to analyse the class profile of social democracy and define a working-class party. The leading idea is that social democracy as a working-class party does not per se exclude support from other allied classes. I therefore propose a distinction between hybrid and pure working-class parties. The chapter demonstrates the relatively strong working-class character of social democracy in six Western European countries. The analysis focuses on the 1970s because this period still featured the 'Keynesian class compromise' (although it started to be in serious crisis) and comparative survey data are available.
\end{abstract}

Keywords Voting · Social democracy · Working class · Working-class party

(C) The Author(s) 2020

L. Rennwald, Social Democratic Parties and the Working Class, Challenges to Democracy in the 21 st Century, https://doi.org/10.1007/978-3-030-46239-0_3 


\section{Conceptualising the Relationship Between Social Democracy and Social Classes}

In order to determine the class profile of social democracy, it is necessary to capture the relation of social democracy to its core electorate of the working class, as well as to other potentially allied classes. As discussed in the previous chapter, the search for alliances has been a primary goal of social democracy. One must therefore consider the possibility that social democracy as working-class parties ${ }^{1}$ does not per se exclude the mobilisation of other classes but is to some extent compatible with the support of other allied classes. At the same time, the specific relationship of social democracy to the working class needs to be emphasised, especially with respect to other parties. If social democracy strongly mobilises the working-class vote, other parties will have difficulty in benefiting from the working-class vote. Hence, social democracy as working-class parties suggests that this party family enjoys a kind of monopoly over the working-class vote.

I propose to think of four ideal types of social democratic party electorates. They combine the support that social democratic parties receive from their core electorate of the working class (first dimension) with the support they receive from allied classes (second dimension). The four types are schematically represented in Fig. 3.1. They rely on different combinations of class support: (1) a pure working-class party relies on strong electoral support from the working class but weak electoral support from allied classes; (2) a bybrid working-class party relies on strong electoral support from both the working class and allied classes; (3) a new class party relies on strong electoral support from allied classes but weak support from the working class; (4) a cross-class party is one with no social group dominant in its electorate.

The combination of these two dimensions allows conceptualisation of the electoral basis of social democracy in a finer way than the previous literature permits. In particular, it makes a more flexible interpretation of working-class parties possible by recognising social democracy's continual search for allies. This is important to establish a baseline for the workingclass character of social democracy as we do in this chapter before turning to the transformations over time. Introducing the hybrid working-class party type includes the possibility that social democracy might mobilise both its core electorate and allied classes. A pure working-class party operates in a situation in which the voting choice is strongly polarised so social 


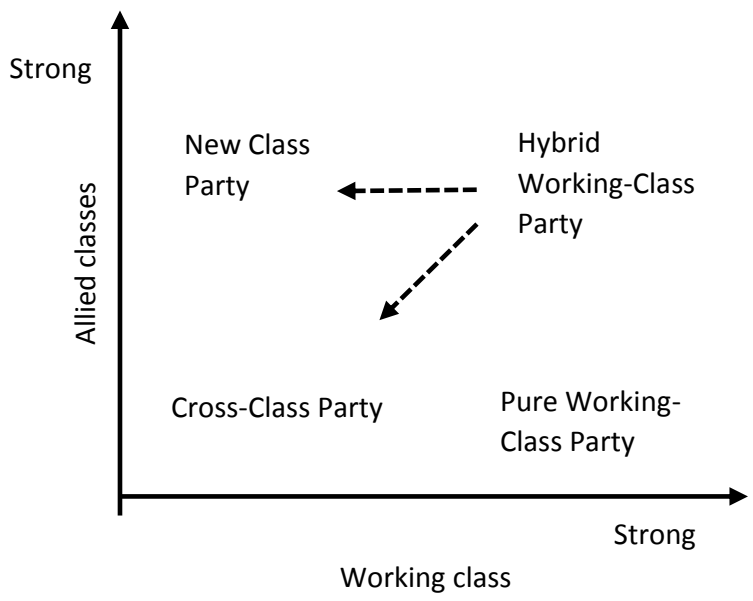

Fig. 3.1 Types of parties according to their support from the working class and allied classes

democracy relies almost entirely on mobilisation of the working class. This situation excludes cases where social democracy can benefit from even intermediate support from other allied classes. I therefore expect social democratic parties in the decades following the war to have been more often closer to the hybrid type of working-class party than to the pure type.

Furthermore, the conceptualisation allows a large range of options in the transformations of the class profile of social democracy to be taken into account. I propose envisaging two options (see the arrows in Fig. 3.1), where social democracy becomes cross-class parties with class no longer relevant in their social base, or it becomes new class parties with a different class replacing the long-term dominance of the working class. Several comparative studies have convincingly demonstrated a decline in manual workers' support for social democracy (e.g. Best 2011; Gingrich and Häusermann 2015; Knutsen 2006; Moschonas 2002) but have not reached a precise conclusion on the new class profile of social democracy. This is partly due to the classical division between manual workers and non-manual workers they use. The work conducted by Moschonas (2002: 83-119) illustrates some of the difficulties met well. Based on a careful compilation of secondary literature, he identifies a reinforcement of a 
second pillar of social democracy voters made up of the salaried middle classes. According to him, the salaried middle classes have the potential to become the new 'centre of the social democratic coalition' as was previously the case for the working class (Moschonas 2002: 113). However, he points to a strong variation in national situations and the important heterogeneity in the salaried middle classes-an element he cannot fully examine with the broad groupings of occupations he uses.

Moreover, there is a slight tendency to subsume social democracy's contemporary profile under the 'middle-class parties' heading, given the general rise of middle-class occupations relative to blue-collar occupations in the employment structure. Gingrich and Häusermann (2015) carefully inspect the decline in the working-class vote from the 1980s to the 2010s (and as its consequences for the elaboration of social policies). The authors are able to show a process in which parties of the $\operatorname{left}^{2}$ can compensate for the decline in working-class support with new support from middle-class constituencies. Their results for the class composition of left-wing party supporters indicate that middle-class voters represent an increasing part of social democracy's electoral base-and manual workers a decreasing part. More precisely, they show that since the 1990s middleclass voters have represented a larger part of the electoral base than manual workers. ${ }^{3}$ Their analysis on the transformation of the class composition is extremely interesting but it does not really take into consideration changes in class structure. Similar results may be found for all political parties given the general decline in blue-collar occupations and the concomitant rise in middle-class occupations.

What makes a cross-class party distinctive is its absence of support from specific social classes-but not an absence of support as such. The working class does not have a dominant position for this type. Support from the working class is no longer distinct from that from other classes, including traditionally opposed classes. There is a strong proximity between the cross-class party type and the catch-all party model (see the previous chapter). I preferred the label 'cross-class party' to the more encompassing concept of 'catch-all party', which not only refers to the electorate but also to the ideology of parties. Furthermore, as I argued in the preceding chapter, the initial idea of the electorate formulated by Kirchheimer (1966) refers more to a restrictive opening to other classes than to a broad opening of socialist parties to all social classes. Hence, Kirchheimer's formulation refers more to the hybrid working-class party type, 
which has a combination of strong support from the working class and intermediate support from allied classes.

The 'new class' type is intimately related to the close proximity between specific segments of the salaried middle classes and left-wing parties. The idea of a new class refers to the expansion of the new middle classes in social structure. ${ }^{4}$ Several scholars have emphasised the strong left-wing potential among professionals in social and cultural services, the 'sociocultural professionals' in the Oesch class schema (e.g. Kitschelt 1994; Kriesi 1998). Indeed, research has shown differences in party preferences, with socio-cultural professionals leaning to the left (and especially towards the Greens) and managers - the salaried arm of owners and employersleaning to the right (e.g. Dolezal 2010; Güveli et al. 2007; Müller 1999; Oesch 2008). Hence, in the recent period, the allied classes have typically included socio-cultural professionals. In previous periods, lowerrank white-collar workers (service workers and clerks in the Oesch class schema) formed the backbone of allied classes (see the previous chapter). Instead of collapsing all white-collar workers into a unique category, the Oesch class schema allows us to capture these classes with precision while also offering flexibility to deal with the rise of new allies over time.

What does strong electoral support from a class mean? It is possible to consider the question from two different angles. First, it is possible to think about the distinctiveness of a specific social class in its vote choice. The extent to which a social class gives support to a political party that is different from the average vote choice indicates a close affinity between a specific social class and a specific party. This factor has been at the centre of research on cleavages (and the decline in cleavages), where attention has been given to the "partisan alignments of specific groups comprising cleavages" (Brooks et al. 2006: 91). However, scholarly research has also pointed to the importance of changes in the size of the groups comprising cleavages, most notably to the reduction in the size of the industrial working class. In this perspective, cleavages become weaker, not only or simply because groups change their political preferences ('behavioural dealignment') but simply because they lose their prominence in the social structure ('structural dealignment') (e.g. Best 2011; Goldberg 2017, 2019; Lachat 2007; Manza and Brooks 1999). One must therefore also consider the electoral relevance of a specific social class for a party. The extent to which a social class represents a large share of a party's voters indicates the dependency of the party on that specific social class for its electoral results. This factor depends on the size of 
the group in the social structure-it is more likely that a social class is important to a party's score if the class represents a strong proportion of the total potential electorate. It also depends on the specific group's turnout-it is more likely that a social class is important to a party's score if the class displays a strong turnout. ${ }^{5}$

In order to tap into the electoral support from social classes, I therefore propose to use two indicators: the vote of workers (and allied classes) in relation to the average party score and the contribution of workers (and allied classes) to the electoral score of social democratic parties in relation to their weight in the social structure. For each element, I will not only consider the absolute level of support for social democracy but will also consider the relative level by means of ratios relating the level of support from a given class to a party's average level of support. This will allow me to take into account variations in parties' electoral popularity, as is emphasised in class voting research (Evans 1999: 13-14).

\section{Social Democracy as Hybrid Working-Class Parties in the i97os}

I focus on one election in the first half of the 1970s and use the crossnational 'Political Action: An Eight Nation Study, 1973-1976' survey. This survey included a question on the party voted for in the last national parliamentary election and detailed information on the respondents' occupations. Since France was not included in this survey, I use the post-electoral survey for the 1978 legislative election (first round). Manufacturing was still predominant during the decade in questionemployment in the industrial sector peaked in 1970 in Europe (Therborn 1995: 71) and large demographic earthquakes did not affect the industrial working class until the 1980s (Hobsbawm 1994). Moreover, in the period of economic expansion that started after the Second World War and lasted until the recession of 1973-1975, social democratic parties reached a peak in terms of ideological influence, public policies and electoral performances $^{6}$ (Escalona 2018: 27). Focusing on the 1970s makes possible to study the electoral base of social democracy during this successful period. There are also pragmatic reasons for making a comparison with this decade. If one puts aside the British case, this is when surveys emerged.

Let us start with the extent to which social democracy reached a high score among workers. Figure 3.2 displays support for social democratic parties by social class, with the parties' average score on the vertical 
a) AT: SPÖ 1971 (mean: 55.9\%)

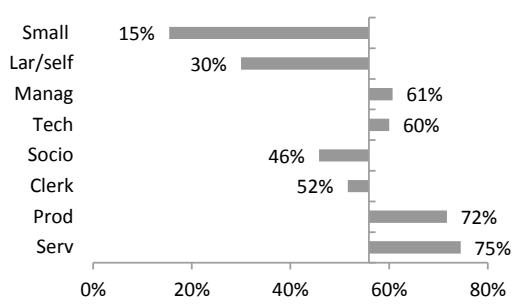

c) DE: SPD 1971 (mean: 42.9\%)

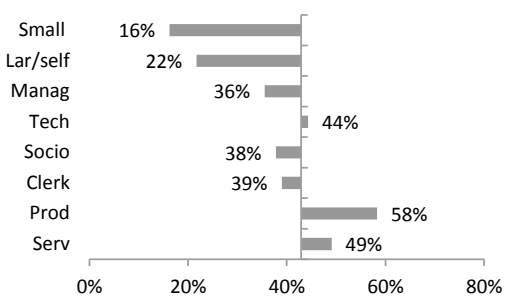

e) NL: PvdA 1972 (mean: 35.9\%)

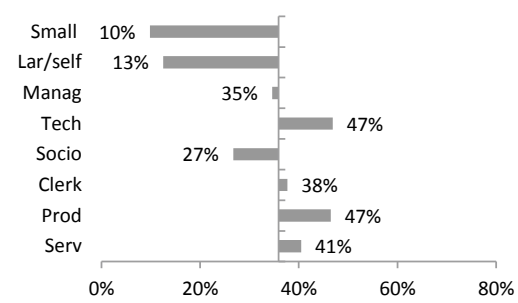

b) GB: Labour 1970 (mean: 46.5\%)

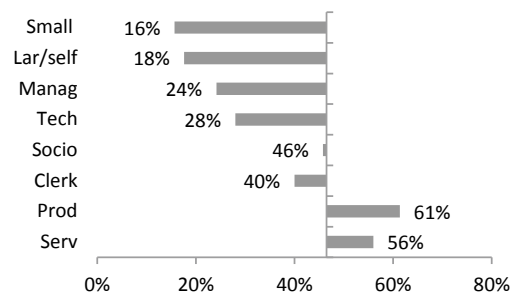

d) FR: PS 1978 (mean: 24.9\%)

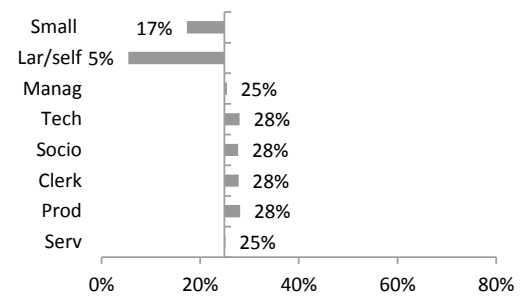

f) $\mathrm{CH}$ : SPS 1975 (mean: 31.3\%)

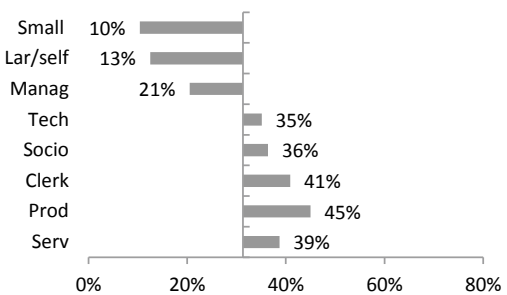

Fig. 3.2 Support for social democratic parties by social class in six countries in the $1970 \mathrm{~s}$

Notes The election year is given in the headings. Numbers of cases: AT: 1018, GB: 682, DE: 1480, FR: 3456, NL: 713, CH: 447. Source Political Action: An Eight Nation Study, 1973-1976, distributed by GESIS www.gesis.org (ZA0765). For France: Enquête post-électorale française 1978, CEVIPOF, distributed by the Centre de Données Socio-politiques, http://cdsp.sciences-po.fr

Names of classes: Small $=$ small business owners, Lar $/$ self $=$ large employers and self-employed professionals, Manag $=$ managers, Tech $=$ technical professionals, Socio $=$ socio-cultural professionals, Clerk $=$ clerks, Prod $=$ production workers, Serv $=$ service workers 
axis. ${ }^{7}$ In all the countries examined with the exception of France, production workers were the strongest supporters of social democracy/labour and the difference vis-à-vis the average supporter reached around 15 percentage points. In absolute terms, social democratic parties received between 60 and $70 \%$ of the working-class vote in Austria, Great Britain and Germany and slightly under half the working-class vote in the Netherlands and Switzerland. In relative terms, production workers' support for social democratic parties exceeded average support by a factor of 1.28 in Austria, 1.32 in Great Britain, 1.36 in Germany, 1.30 in the Netherlands and 1.44 in Switzerland. The conclusion is the same if one uses either absolute or relative support. Without any doubt, social democracy received strong support from the working class in the 1970s.

Social democratic parties obtained weak scores among small business owners, large employers and self-employed professionals. However, they benefited from an intermediate level of support from various other classes. Most distinctively, they were particularly successful among service workers-a relatively small group at the time, as we will see laterin several countries. They also enjoyed intermediate to above-average support from clerks, socio-cultural professionals and in some countries technical professionals and managers. This suggests that already in the 1970s social democracy could not be described as a purely working-class movement.

The French Socialist Party had a different class profile in 1978. Its penetration among production workers was much smaller (a ratio of 1.13). Moreover, production workers did not outdistance various other groups of wage earners. The cross-class (or 'interclassist') character of the French Socialist Party is often emphasised in the literature (e.g. Rey 2004; Lefebvre and Sawicki 2006). The main reason for this was the presence of the Communist Party (see Michelat and Simon 2004; Mischi 2010; Moschonas 2002), which was the first party chosen by production workers in France according to our results. On average, the Communist Party received $21 \%$ of the vote but it gathered $36 \%$ of production workers' votes (a ratio of 1.71). Together, the Socialist Party and the Communist Party obtained $64 \%$ of production workers' votes, a level no different from elsewhere. The Communist Party also received intermediate support from service workers, clerks and technical professionals (19-21\%) but reached lower levels among socio-cultural professionals (17\%), managers (14\%) and especially small business owners and large employers/self-employed professionals (7\%). Even the Communist Party could not be described as a 
pure working-class party in the 1970s because it reached an intermediate level of support from a mix of classes.

The analysis has so far been restricted to workers who participated in the election. We must now analyse the basic question of the levels of participation of the different social classes. It is striking to observe from Table 3.1 that production worker participation did not differ very much from the average level in several of the countries. This was especially the case in Austria and France. In Austria, for example, they were almost as likely to turn out as large employers and self-employed professionals. There were more inequalities in other countries. In Great Britain and the Netherlands, production workers were the group that participated the least in elections, and they were the group that participated secondleast after service workers in Germany and Switzerland. By contrast, the salaried middle classes and large employers generally displayed the highest levels of participation.

The importance of production workers in the employment structure in the 1970s made social democratic support logically composed of production workers to a large extent. It is therefore necessary to observe, in relative terms, the extent to which social democratic party electorates were more working class than the total electorate. Again using the 8class schema, Table 3.2 presents the composition of social democratic party electorates and for comparison purposes the composition of the total electorates (including the people who did not vote).

Austria and Great Britain were the two countries where social democracy obtained the highest shares of production workers' votes (see Figure 3.2) and production workers contributed the most to this party

Table 3.1 Participation by social class in the 1970s (in \%)

\begin{tabular}{llllllllll}
\hline & Prod & Serv & Clerk & Socio & Tech & Manag & Lar $/$ self & Small & Mean \\
\hline AT & 91 & 89 & 89 & 96 & 88 & 92 & 92 & 96 & 92 \\
GB & 68 & 80 & 74 & 76 & 87 & 73 & 72 & 81 & 73 \\
DE & 89 & 88 & 94 & 98 & 96 & 99 & 100 & 96 & 93 \\
FR & 93 & 92 & 93 & 92 & 90 & 95 & 100 & 95 & 94 \\
NL & 72 & 78 & 80 & 90 & 84 & 89 & 89 & 86 & 80 \\
CH & 51 & 38 & 59 & 67 & 65 & 75 & 74 & 54 & 57 \\
\hline
\end{tabular}

Notes Number of cases: AT: 1256, GB: 992, DE: 1751, FR: 3809, NL: 921, CH: 920. See the information under Fig. 3.2 for sources and names of classes 
Table 3.2 Composition of social democratic party electorates and total electorates in the 1970s (in \%)

\begin{tabular}{rlrrrrrrrr}
\hline & & Prod & Serv & Clerk & Socio & Tech & Manag & Lar/self & Small \\
\hline \multirow{2}{*}{ AT } & SPÖ & 46 & 19 & 12 & 5 & 2 & 11 & 1 & 5 \\
& Total & 35 & 14 & 13 & 5 & 2 & 11 & 1 & 19 \\
GB & Labour & 49 & 18 & 16 & 7 & 2 & 5 & 1 & 3 \\
& Total & 39 & 14 & 18 & 7 & 3 & 9 & 3 & 7 \\
DE & SPD & 38 & 17 & 18 & 7 & 6 & 10 & 1 & 4 \\
& Total & 30 & 15 & 19 & 7 & 5 & 12 & 1 & 11 \\
FR & PS & 31 & 13 & 18 & 12 & 4 & 12 & 1 & 12 \\
& Total & 27 & 13 & 16 & 11 & 4 & 11 & 2 & 18 \\
NL & PvdA & 29 & 20 & 22 & 9 & 6 & 11 & 1 & 2 \\
& Total & 25 & 19 & 21 & 11 & 4 & 9 & 2 & 8 \\
CH & SPS & 36 & 9 & 19 & 9 & 9 & 11 & 2 & 5 \\
& Total & 31 & 11 & 14 & 7 & 7 & 13 & 4 & 15 \\
\hline
\end{tabular}

Notes See the information under Fig. 3.2 for sources, names of classes and numbers of cases (see also Table 3.1). The total electorate includes non-voters and therefore refers to the population entitled to vote

family's electoral results. They represented almost one in two social democratic voters in these countries-this was also the case of the Communist Party in France, with $47 \%$ of its votes coming from production workers. They made up more than a third of the social democratic electorates in Germany and Switzerland but less than a third in France and the Netherlands. Social democratic parties were clearly helped by the class structure of the time but their supporters were, in relative terms, much more working class than the total electorate, especially in Austria (ratio: 1.31), Germany (ratio: 1.27) and Great Britain (ratio: 1.26). The contrast with the mainstream right-wing parties is also instructive. Production workers represented a non-negligible share of the centre-right parties' electorates but they never constituted more than approximately a quarter of them in all the countries of our sample.

While the importance of production workers in the social democratic electorate is evident, it does not go beyond the $50 \%$ threshold. Social democratic/socialist/labour parties were therefore dependent on mobilising allied classes to some extent, in particular lower white-collar workers. This again suggests that social democratic parties were not pure workingclass parties in the 1970s. Service workers and clerks together represented around a third of the social democratic electorate at the time-less than a 
third in Austria (27\%) and Switzerland (28\%) to be more precise. The proportion even reached $42 \%$ in the Netherlands. The Dutch Labour Party could clearly compensate for the relatively small size of production workers in the Netherlands.

By contrast, the salaried middle classes represented less than a fifth of the social democratic electorates in Austria and Great Britain (18 and $14 \%$ if one adds the shares of socio-cultural professionals, technical professionals and managers) and around a quarter in the other countries. The proportion reached $29 \%$ in Switzerland and thus equalled the level of lower white-collar workers. The proportion is also relatively high for the cross-class French Socialist Party $(28 \%)$. The stronger role of lower whitecollar workers relatively to that of the salaried middle classes is also a product of the class structure. The salaried middle classes represented small groups in the total electorate at the time.

The analyses focusing on the distinctiveness of the working class in its vote and the contribution of the working class to social democracy's electoral score point to similar logics. This party family mobilised production workers relatively strongly. However, no social democratic party came close to the ideal type of pure working-class (or production workers') party. Service workers were often as distinctive in their support for social democracy as production workers and contributed to its electoral scores. One must therefore think of social democratic parties in the 1970s as alliances between blue-collar workers and lower whitecollar workers, who together represented a significant share of the total eligible electorate. It is therefore more appropriate to use the concept of hybrid working-class parties. The observations made by Kirchheimer in 1966 that social democracy could successfully open to other segments of the electorate seem to be correct. Social democracy strongly mobilised production workers but at the same time managed to mobilise lower white-collar workers.

However, the analysis has also demonstrated some considerable crossnational variation. The British Labour Party and the Austrian Social Democratic Party were the parties going the most in the direction of pure working-class parties because they mobilised production workers' votes the most strongly. By contrast, the French Socialist Party mobilised production workers and allied classes at similar levels and therefore had affinities with the cross-class type. The Dutch Labour Party reached stronger mobilisation among lower non-manual workers than among production workers. The Swiss Social Democratic Party mobilised 
production workers relatively well but at the same time already had a more diverse profile than in other countries.

The finding that social democratic parties are not pure working-class parties is not dramatically new. Indeed, it is in line with several studies that have emphasised diversity in social democracy's electoral support in the decades following the war. For example, in her analysis of Eurobarometer survey data, Best (2011) underlines the importance of the non-manual population in social democratic vote shares in the mid-1970s. Moschonas (2002: 50-51) characterises social democracy in the 1950s and 1960s as an 'enlarged coalition of the working class'. According to him, there was a strong predominance of the working-class electorate in its social basis but at the same time social democracy could benefit from some support from the salaried middle classes. Bergounioux (1989) also insisted on the early transformation of the class composition of social democratic parties (before 1914) and their opening towards other groups of wage earners. However, in the context of recent discussions about the transformations of social democracy, it is essential to remember the hybrid character of social democracy and to carefully consider the baseline, as we do in this chapter.

Finally, one might also wonder whether the combination of production workers' support with that of other classes observed already signals an important transformation in the class profile of social democracy. One can read the results in two different directions: as representative of social democracy's original ambition to appeal to allied classes or as indicating a transformation of social democracy in which there is a trade-off between working-class and middle-class support (Przeworski and Sprague 1986). It is not clear which direction is the more accurate. Nonetheless, it is interesting to observe that the mobilisation of production workers remained at a relatively high level in the 1970s-which is different from what we will observe in the next chapter for the more recent period.

\section{Dominance Over the Working-Class Vote}

Logically, strong working-class mobilisation by social democracy also prevents other parties from penetrating this segment of the electorate. I now consider the competition that social democracy faces for its core electorate. Three scenarios are possible. First, a social democratic party may be the only party that captures most of the working-class vote and there is no other serious competitor. Second, a social democratic party may 
compete with another party for the working-class vote. Third, there can be open competition among several (or all) parties for the working-class vote. Analogously to the typology developed by Oesch and Rennwald (2018), the working class forms the party preserve of social democracy in the first scenario. In the second case, the working class is the contested stronghold of two parties, and in the third case, there is open competition between parties. One can therefore analyse the type of competition by considering the number of parties which receive above-average electoral support from the working class.

Next to communist parties, Christian Democratic parties were potential competitors for the working-class vote in the 1970s. Their cross-class appeal and support represent an important characteristic of this party family (Duncan 2015; Kalyvas and van Kersbergen 2010; Knutsen 2006). However, as we will see, in most cases, Christian Democratic parties did not receive above-average support from production workers. Social democracy therefore enjoyed a sort of monopoly over the representation of production workers in most of the countries. Thus, production workers constituted the party preserve of social democracy.

In Austria, a quarter of the production workers' votes went to the Austrian People's Party (ÖVP), which obtained an average of 39\% of the vote share-the ratio is therefore 0.64. In Great Britain, the Conservatives gathered $31 \%$ of production workers' votes, against $46 \%$ of the total electorate's (a ratio of 0.67). In Germany, the Christian Democratic Union (CDU) enjoyed $35 \%$ of the production workers' votes, compared with an overall average of $43 \%$ (a ratio of 0.81 ). In Switzerland, the party second-best supported by production workers was the Christian Democratic People's Party (CVP) (18\% of production workers' votes against $20 \%$ overall, a ratio of 0.9 ), and the Radical Democratic Party (FDP) was only the third party, with $13 \%$ of the workers' votes (against $22 \%$ overall, a ratio of 0.59 ). Around $20 \%$ of production workers' votes went to other smaller parties in the fragmented Swiss party system.

The cross-class character of Christian democracy was more visible in Switzerland and Germany than in Austria. However, it was most pronounced in the case of the Netherlands. The three confessional parties merging in 1977 in the Christian Democratic Appeal (CDA) received $36 \%$ of production workers' votes, against an average of $32 \%$ (a ratio of 1.12). This was the only case in our sample where two parties received above-average electoral support from production workers. The People's 
Party for Freedom and Democracy (VVD) received only $2.5 \%$ of production workers' votes but it gathered $14 \%$ of the votes on average (a ratio of 0.18). Production workers were therefore the contested strongholds of both social democracy and Christian democracy in this country. The Netherlands therefore represented an exception to the monopoly of social democracy.

Finally, the importance of competition with the Communist Party in France has already been mentioned. It should be added that the Gaullist and non-Gaullist centre-right parties both received around 14\% of production workers' votes and each gathered an average of 20-21\% of the overall vote (a ratio of 0.67 ). Production workers were therefore the contested strongholds for both social democracy and communism in France.

\section{SUMMING UP}

The results presented in this chapter indicate that in the 1970s social democracy relied on strong support from production workers, who generally had a relatively high level of participation in elections. However, several elements indicate that social democracy also relied on the mobilisation of other allied classes. It reached a medium level of support among various segments of wage earners and especially among service workers. Lower non-manual classes also brought a non-negligible contribution to the electoral results of social democratic parties. Social democracy in the 1970s therefore cannot be described as a pure working-class movement. This party family came closer to the ideal type of hybrid working-class party. However, there was also some considerable cross-national variation. Some social democratic parties were clearly less hybrid than others, in particular when they faced no competition from Christian Democrats. When social democracy faced significant competition from communists, it also had a tendency to display affinities with the cross-class party type, as in the case in France.

\section{Notes}

1. I leave aside here the question of the representation of interests and focus purely on the sociology of the electorate.

2. Gingrich and Häusermann consider the combined support for social democratic, communist and green parties. However, they mention that their 
results are similar if they only focus on social democratic parties (see also Häusermann 2018).

3. It should be added that their empirical analysis is based on data from the Eurobarometer, where respondents' occupations are classified according to the blue-collar vs. white-collar distinction. Constrained by the data, the authors group an important part of lower white-collar workers (skilled service workers) with the middle class. This produces an over-large segment of middle-class voters, or at least a larger segment than I use in this study.

4. The term 'new class' was originally used by American social scientists (e.g. Gouldner 1979; see also Brint 1985) and conservative thinkers to grasp the rise of liberalism and dissent among American professionals in the late 1960s.

5. In an analysis of Republican and Democrat voters, Axelrod (1972) proposed that the contribution of a given group to a party's score must be seen as a combination of the loyalty of the group to the political party, its turnout and its size (for recent applications, see Best 2011; Bürgisser and Kurer 2019).

6. The detailed vote shares obtained by social democratic parties are available in Appendix.

7. The average vote shares are derived from the survey. The data have not been weighted to adjust for the official election results.

\section{REFERENCES}

Axelrod, R. (1972). Where the Votes Come From: An Analysis of Electoral Coalitions, 1952-1968. The American Political Science Review, 66(1), 11-20. Bergounioux, A. (1989). Un parti ouvrier. In A. Bergounioux \& B. Manin (Eds.), Le régime social-démocrate (pp. 13-21). Paris: Presses universitaires de France.

Best, R. E. (2011). The Declining Electoral Relevance of Traditional Cleavage Groups. European Political Science Review, 3(2), 279-300.

Brint, S. (1985). The Political Attitudes of Professionals. Annual Review of Sociology, 11, 389-414.

Brooks, C., Nieuwbeerta, P., \& Manza, J. (2006). Cleavage-Based Voting Behavior in Cross-national Perspective: Evidence from Six Postwar Democracies. Social Science Research, 35, 88-128.

Bürgisser, R., \& Kurer, T. (2019). Social Democratic Labor Market Policy in Post-Industrial Societies. Socio-Economic Review, online first.

Dolezal, M. (2010). Exploring the Stabilization of a Political Force: The Social and Attitudinal Basis of Green Parties in the Age of Globalization. West European Politics, 33(3), 534-552. 
Duncan, F. (2015). Preaching to the Converted? Christian Democratic Voting in Six West European Countries. Party Politics, 21(4), 577-590.

Escalona, F. (2018). La reconversion partisane de la social-démocratie européenne. Du régime social-démocrate keynésien au régime social-démocrate de marché. Paris: Dalloz.

Evans, G. (1999). Class Voting: From Premature Obituary to Reasoned Appraisal. In G. Evans (Ed.), The End of Class Politics? Class Voting in Comparative Context (pp. 1-20). Oxford: Oxford University Press.

Gingrich, J., \& Häusermann, S. (2015). The Decline of the Working-Class Vote, the Reconfiguration of the Welfare Support Coalition and Consequences for the Welfare State. Journal of European Social Policy, 25(1), 50-75.

Goldberg, A. (2017). The Impact of Cleavages on Swiss Voting Behaviour: A Modern Research Approach. Cham: Springer.

Goldberg, A. C. (2019). The Evolution of Cleavage Voting in Four Western Countries: Structural, Behavioural or Political Dealignment? European Journal of Political Research, 59(1), 68-90.

Gouldner, A. (1979). The Future of Intellectuals and the Rise of the New Class. New York: Seabury.

Güveli, A., Need, A., \& De Graaf, N. D. (2007). The Rise of 'New' Social Classes Within the Service Class in The Netherlands: Political Orientation of Social and Cultural Specialists and Technocrats Between 1970 and 2003. Acta Sociologica, 50(2), 129-146.

Häusermann, S. (2018). Social Democracy and the Welfare State in Context: The Conditioning Effect of Institutional Legacies and Party Competition. In P. Manow, H. Schwander, \& B. Palier (Eds.), Welfare Democracies and Party Politics: Explaining Electoral Dynamics in Times of Changing Welfare Capitalism (pp. 150-170). Oxford: Oxford University Press.

Hobsbawn, E. (1994). The Age of Extremes: The Short Twentieth Century, 19141991. London: Michael Joseph.

Kalyvas, S. N., \& van Kersbergen, K. (2010). Christian Democracy. Annual Review of Political Science, 13(1), 183-209. https://doi.org/10.1146/ann urev.polisci.11.021406.172506.

Kirchheimer, O. (1966). The Transformation of the Western European Party Systems. In J. Lapalombara \& M. Weiner (Eds.), Political Parties and Political Development (pp. 177-200). Princeton: Princeton University Press.

Kitschelt, H. (1994). The Transformation of European Social Democracy. New York: Cambridge University Press.

Knutsen, O. (2006). Class Voting in Western Europe: A Comparative Longitudinal Study. Lanham, MD: Lexington Books.

Kriesi, H. (1998). The Transformation of Cleavage Politics: The 1997 Stein Rokkan Lecture. European Journal of Political Research, 33(2), 165-185. 
Lachat, R. (2007). A Heterogeneous Electorate: Political Sophistication, Predisposition Strength, and the Voting Decision Process. Baden-Baden: Nomos Verlag.

Lefebvre, R., \& Sawicki, F. (2006). La société des socialistes: le PS aujourd'hui. Bellecombe-en-Bauges: Ed. du Croquant.

Manza, J., \& Brooks, C. (1999). Group Size, Turnout, and Political Alignments and the Development of U. S. Party Coalitions, 1960-1992. European Sociological Review, 15(4), 369-389.

Michelat, G., \& Simon, M. (2004). Les Ouvriers et la Politique: Permanence, Ruptures, Réalignements 1962-2002. Paris: Presses de sciences po.

Mischi, J. (2010). Servir la classe ouvrière. Sociabilités militantes au PCF. Rennes: Presses universitaires de Rennes.

Moschonas, G. (2002). In the Name of Social Democracy: The Great Transformation, 1945 to the Present. London: Verso.

Müller, W. (1999). Class Cleavages in Party Preferences in Germany-Old and New. In G. Evans (Ed.), The End of Class Politics? (pp. 137-180). Oxford: Oxford University Press.

Oesch, D. (2008). The Changing Shape of Class Voting: An Individual-level Analysis of Party Support in Britain, Germany and Switzerland. European Societies, 10(3), 329-355.

Oesch, D., \& Rennwald, L. (2018). Electoral Competition in Europe's New Tripolar Political Space: Class Voting for the Left, Centre-Right and Radical Right. European Journal of Political Research, 57(4), 783-807.

Przeworski, A., \& Sprague, J. (1986). Paper Stones: A History of Electoral Socialism. Chicago: University of Chicago Press.

Rey, H. (2004). La gauche et les classes populaires: histoire et actualité d'une mésentente. Paris: La Découverte.

Therborn, G. (1995). European Modernity and Beyond: The Trajectory of European Societies, 1945-2000. London: Sage. 
Open Access This chapter is licensed under the terms of the Creative Commons Attribution 4.0 International License (http://creativecommons.org/licenses/ by $/ 4.0 /$ ), which permits use, sharing, adaptation, distribution and reproduction in any medium or format, as long as you give appropriate credit to the original author(s) and the source, provide a link to the Creative Commons license and indicate if changes were made.

The images or other third party material in this chapter are included in the chapter's Creative Commons license, unless indicated otherwise in a credit line to the material. If material is not included in the chapter's Creative Commons license and your intended use is not permitted by statutory regulation or exceeds the permitted use, you will need to obtain permission directly from the copyright holder.

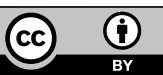

